American Journal of Environmental Sciences 4 (6): 551-557, 2008

ISSN 1553-345X

(C) 2008 Science Publications

\title{
Effects of Fertilization and Clipping of Phlomis fruticosa L. on a Phryganic Ecosystem: The Case of Thesprotia, Northwest Greece
}

\author{
${ }^{1}$ Ch. Roukos, ${ }^{1}$ K. Papanikolaou, ${ }^{2}$ E. Nikolaou, \\ ${ }^{3} \mathrm{~F}$. Chatzitheodoridis and ${ }^{1} \mathrm{I}$. Mountousis \\ ${ }^{1}$ Aristotle University of Thessaloniki, 54006 Thessaloniki, Greece \\ ${ }^{2}$ Technological Educational Institution of Epirus, 48100 Arta, Greece \\ ${ }^{3}$ Technological Educational Institution of Western Macedonia, 53100 Florina, Greece
}

\begin{abstract}
This study examined the effectiveness of various shrub control treatments $(\mathrm{N}+\mathrm{P}$ fertilization, clipping of Phlomis fruticosa and clipping combined with $\mathrm{N}+\mathrm{P}$ fertilization), to reduce shrub cover and encourage the growth of palatable herbaceous vegetation. Dry matter production and Crude Protein (CP) content of palatable herbaceous vegetation were determined annually from 2004 to 2006. Experimental plots received rains of 691.7, 532.9 and $595.7 \mathrm{~mm}$ during the 3 study years compared to mean growing season rainfall of $486.6 \mathrm{~mm}$. Forage production was increased significantly by clipping of Phlomis fruticosa (409.4 vs $\left.335.5 \mathrm{~g} \mathrm{DM} \mathrm{m}^{-2}, \mathrm{p}<0.05\right)$ and clipping combined with $\mathrm{N}+\mathrm{P}$ fertilization ( 454.6 vs $335.5 \mathrm{~g} \mathrm{DM} \mathrm{m}^{-2}, \mathrm{p}<0.05$ ). On average over the 3 years, crude protein concentration increased by fertilization (9.18 vs $8.26 \%, \mathrm{p}<0.05)$ and fertilization combined with clipping of Phlomis fruticosa (9.35 vs $8.26 \%, \mathrm{p}<0.05)$. N and P fertilization combined with clipping of Phlomis fruticosa significantly ( $\mathrm{p}<0.05$ ) affected S-RUE. The highest S-RUE of 3.09 $\mathrm{kg}$ forage ha $\mathrm{ha}^{-1} \mathrm{~mm}^{-1}$ was obtained with $\mathrm{N}+\mathrm{P}$ fertilization combined with clipping of Phlomis fruticosa. On average over the 3 years, nutrient use efficiency with $\mathrm{N}+\mathrm{P}$ application combined with clipping of Phlomis fruticosa for all treatments was higher than without clipping. The increases in plant production per $\mathrm{kg}$ fertilizer applied, for $\mathrm{N}+\mathrm{P}$ application both and without clipping of Phlomis fruticosa $\mathrm{L}$. were 21.10 and $59.50 \mathrm{~kg}$, respectively. Effective improvement of rangeland dominated by Phlomis fruticosa requires, most probably, a combined treatment including removal of mature Jerusalem sage shrubs, suppressing their recovery and stimulating the competing forage component. However, it is proposed the application of clipping of Phlomis fruticosa for a period of at least three years to avoid unfavourable environmental effects from fertilization.
\end{abstract}

Key words: $\mathrm{N}+\mathrm{P}$ fertilization, clipping, Phlomis fruticosa $\mathrm{L}$, phryganic ecosystems, rangelands

\section{INTRODUCTION}

Plant communities dominated by Phlomis fruticosa L., a semi-deciduous drought-hardy and flammable dwarf shrub of about $150 \mathrm{~cm}$ tall $^{[8]}$, are a common vegetation type in western Greece. In Greece, such communities are known as phrygana and they are widespread in areas with long, dry and hot summers and mild and rainy winters ${ }^{[26]}$. They usually grow on dry, rocky and friable soils without active calcium ${ }^{[6]}$.

Physiognomically, phrygana can compare with the coastal sage in California and garrigue in France ${ }^{[18]}$. In Mediterranean type ecosystems, the phrygana are adopted a drought semi-deciduous habit, thus avoiding excessive water loss during the dry period ${ }^{[22]}$. These shrubs have been frequently called seasonally dimorphic $^{[17,18,20,38]}$.
Phryganic communities of Phlomis fruticosa are an important component of livestock farming systems covering up to $47.5 \%(40,000 \mathrm{ha})$ of the total rangelands in Thesprotia Prefecture ${ }^{[1]}$. They provide forage and bedding for sheep, primarily and they make productive use of rocky and marginal soils that are unsuitable for field and vegetable crops.

Phlomis fruticosa, however, is unpalatable to farm animals which they consume it tender stems rarely. In places where it gets dense, free movement of sheep becomes impossible and considerable area of valuable grazing land is thus lost $\mathrm{t}^{[24]}$.

To control this troublesome species and to, consequently, increase the grazing capacity of the phryganic rangelands, shepherds have been using fire for a long time. However, the fires set by those people

Corresponding Author: Fotis Chatzitheodoridis, Technological Educational Institution of Western Macedonia, Terma Kontopoulou Str., -53100 Florina-Greece 
are uncontrolled and usually have more harmful than desirable effects ${ }^{[23]}$.

In Greece, application of fertilizer on mountainous rangelands was been taken place until 1980 decade in order to increase rangeland production. However, it results in unfavourable environmental impacts (mainly pollution of surface and underground waters) because of the high rainfall in combination with the calcaceous soil substrates of regions where it was applied.

Fertilizer application can improve productivity by affecting forage yield, botanical composition, earliness of spring growth and quality. The application of $\mathrm{N}$ and $\mathrm{P}$ generally alters species composition and increases dry matter and crude protein yields ${ }^{[2,3,12,25,34]}$. Other studies, although, have reported that annual fertilization resulted in lower above-ground biomass and tiller density after 3 years $^{[13]}$.

On the other hand, the native pasture ability to sustain animal production is up to their production and nutritive value of pasture ${ }^{[34]}$. Variations in rangeland production are reflected in animal performance ${ }^{[7]}$. In the native phryganic pasturelands, it is important to find out alternative methods by which production can be economically increased without causing unfavorable environmental impacts.

The objective of this research was to study the effects of annual, low-level $\mathrm{N}$ and $\mathrm{P}$ fertilization and clipping of Phlomis fruticosa on above-ground biomass production, crude protein content of forage, seasonal rain use efficiency, nutrient use efficiency and grazing capacity in Thesprotia rangelands.

\section{MATERIALS AND METHODS}

This study was conducted at Karvounari (lat $39.3661^{\circ}$, long $20.4926^{\circ}$, elevation $380 \mathrm{~m}$ ) Thesprotia Prefecture, north-west Greece between February 2004 and July 2006. The climate is temperate-warm. Mean monthly temperature range from $8.7^{\circ} \mathrm{C}$ in January to $26.4^{\circ} \mathrm{C}$ in July. Mean annual rainfall for 1951-2001 was $1.344,9 \mathrm{~mm}$ (SD $= \pm 286$, 6) with nearly $36.2 \%$ occurring during the growing season (February to June $)^{[36]}$. Soils are calcaceous with $\mathrm{pH}, 7.1-7.8$, insufficiently provided in N, P and K. Geologically, the plain belongs to the Ionian geotectonic zone. The basic substrates are dolomites, Viglas limestones and flisch $^{[27]}$.

The botanical analysis of experimental area based on frequency of occurring in sixteen quadrates, each equals $1 \mathrm{~m}^{2}$, in May 2004. The number of taxa was found to be 192: 33 legumes, 38 grasses and 121 of other families.
The most dominated legumes found in the area are the following: Anthyllis hermaniae, Medicago minima, Medicago lupulina, Trifolium arvense, Trifolium campestre, Trifolium purpureum, Trifolium subterraneum, Trifolium repens, Vicia cracca, Vicia villosa and Vicia pubescens; while the grasses are: Avena sterilis, Briza maxima, Bromus sp., Cynodon dactylon, Dactylis glomerata, Hordeum crinitum, Hordeum murinum, Melica ciliate, Phalaris sp., Phleum pretense and Stipa bromoides and others species are: Cistus incanus, Crepis sp., Convolvulus arvensis, Knautia sp., Geranium molle, Teucrium polium, Stachys germanica, Micromeria Juliana, Phleum pratense, Asphodelus albus, Asparagus acutifolius, Plantago bellandii and Galium verum.

In February 2004 four 50×70 m study areas was selected and treatments randomly assigned to 4 plots within each of 4 blocks. Each treatment plot was $11.5 \times 16.5 \mathrm{~m}$ with a distance between plots of $1 \mathrm{~m}$. Treatments were repeated on the same plots for 3 years (2004, 2005 and 2006).

Fertilizer application rate was 0 or $40 \mathrm{~N}$ and $20 \mathrm{P}$ $\left(\mathrm{kg} \mathrm{ha}{ }^{-1}\right)$ in a factorial treatment arrangement. A commercial NP fertilizer $(20 \% \mathrm{~N}, 10 \% \mathrm{P}$ and $12 \% \mathrm{~S})$ was the $\mathrm{N}$ and $\mathrm{P}$ source. Fertilizer was broadcast by hand and then buried by a rake without disturbing the vegetation. The $\mathrm{N}$ and $\mathrm{P}$ were applied at the beginning of growing season (mid-February). The experimental area was excluded from grazing during the experiment.

Herbaceous vegetation was harvested annually within eight, $0.5 \mathrm{~m}^{2}$ permanent quadrats located within each plot when plants were flowering. Vegetation was handclipped at ground level, separated into species, oven dried at $60^{\circ} \mathrm{C}$ and weighed to determine aboveground annual dry matter production of palatable species. Crude protein (CP) of harvested forage was determined using 1 sample of each species per single treatment plot by micro-Kjeldahl $(\mathrm{N} \times 6.25)$, in 2004 , 2005 and 2006.

Seasonal rain-use efficiency (S-RUE) was determined by dividing forage yield over total rainfall of the growing season. From data on fertilizer rate and forage production greater than the yield of no-fertilized plots, nutrient use efficiency was calculated as kg dry matter $\mathrm{kg}^{-1}$ fertilizer applied.

In the present study grazing capacity was calculated based on the follow conservative approach with proper use factor of $50 \%$, (i) Forage intake by cattle is $2.5 \mathrm{~kg}$ DM per day per $100 \mathrm{~kg}$ of liveweight ${ }^{[21,39]}$; (j) Animal units (AU): one $400 \mathrm{~kg}$ cow and calf, or the equivalent, (k) Grazing livestock population of the plain, in AU, for 2004 was found from data provided by Livestock Agency; (1) Cows and sheep grazing for a period of 7 months yearly. 
Three-way Within-Subjects (Repeated Measures) ANOVA was performed for each response variable (forage production, crude protein content and seasonal rain use efficiency) using the SPSS $12.0^{[30]}$. The LSD test ${ }^{[35]}$ was used to assess differences among treatment means $(\mathrm{p}<0.05)$.

\section{RESULTS AND DISCUSSION}

The experimental plots received a total of 691.7 , 532.9 and $595.7 \mathrm{~mm}$ of rainfall during the 2004-2005, 2005-2006 and 2006-2007 growing seasons, which were greater than the long-term mean for the study area (Table 1).

There was a significant yield response to improvement treatments. Application of $\mathrm{N}+\mathrm{P}$ did not affect forage production in 2004 to 2006 (Table 2). Clipping of Phlomis fruticosa and combine of clipping and $\mathrm{N}+\mathrm{P}$ application affected forage production. Forage production from $\mathrm{N}+\mathrm{P}$ application was higher $(\mathrm{p}>0.05)$ than that from no-fertilization. If the average forage productions over the 3 study years are compared, the application of $\mathrm{N}+\mathrm{P}$ did not affect forage production.

Average forage production from $\mathrm{N}+\mathrm{P}$ fertilization and from clipping of Phlomis fruticosa was around 12, 6 and $22 \%$, respectively, above the control. Maximum forage production was achieved from the combine of $\mathrm{N}+\mathrm{P}$ fertilization and clipping of Phlomis fruticosa plots in 2006.
It seems that the high rainfall during the experimental period 2004/06 was insufficiently converted into forage dry material. The main reason for this could be due to the poor range conditions, high density of Phlomis fruticosa and high grazing intensity in these rangelands. However, as the mean annual rainfall in the plain is very high, soil nutrients may be the main limiting factor to forage production. Forage production peaked in the third season in despite on even higher $(5.5 \%)$ rainfall the first season. These results confirm observations made by Kandrelis ${ }^{[14,15]}$, that fertilization of phryganic rangelands did not increase significantly forage production, while clipping of Phlomis fruticosa did.

Furthermore, according to Booysen and Cilliers et al., ${ }^{[4,5]}$ fertilization of rangeland in the higher rainfall areas, usually brings about a dramatic increase in forage production but as the species that constitute the rangelands are adapted to conditions of low soil fertility, the period of high productivity may be followed by an invasion of plant species less acceptable to livestock and with a lower dry matter production.

Crude protein was measured only at the end of the growing season (early June) at flowering time (Table 3). Snyman ${ }^{[33,34]}$ reported that crude protein content of forage is not only a function of the quantity of applied fertilization, but also of climatic condition during growing and developing of plants and also the physiological development phase of plants during its monitoring.

Table 1: Rainfall at paramythia station in 2004-2006, compared to the 40 years mean

\begin{tabular}{|c|c|c|c|c|c|c|c|}
\hline Periods & Feb. & Mar. & $\begin{array}{l}\text { Apr. } \\
- \text {-mm-- }\end{array}$ & May & June & $\begin{array}{l}\text { Growing } \\
\text { season total }\end{array}$ & $\begin{array}{l}\text { Annual total: } \\
\text { Sept-Aug }\end{array}$ \\
\hline $2004-05$ & 191.9 & 242.5 & 100.1 & 106.2 & 51.0 & 691.7 & $1,842.9$ \\
\hline 2005-06 & 244.7 & 169.8 & 63.1 & 44.1 & 11.2 & 532.9 & $1,607.7$ \\
\hline 2006-07 & 193.8 & 235.0 & 94.7 & 37.8 & 34.4 & 595.7 & $1,747.9$ \\
\hline 40-years mean & 188.6 & 121.4 & 98.0 & 53.8 & 24.8 & 486.6 & $1,344.9$ \\
\hline
\end{tabular}

Table 2: Forage production (g DM/ $/ \mathrm{m}^{2}$ ) from 2003/04 to 2005/06 seasons at different treatments

\begin{tabular}{|c|c|c|c|c|}
\hline \multirow[b]{2}{*}{ Treatments } & \multicolumn{3}{|c|}{ Year } & \multirow{2}{*}{$\begin{array}{l}\text { Average } \\
2004-2006\end{array}$} \\
\hline & 2004 & 2005 & 2006 & \\
\hline Control & $246.1 \pm 63.9^{\mathrm{a}}$ & $336.6 \pm 82.2^{\mathrm{a}}$ & $423.9 \pm 98.6^{\mathrm{a}}$ & $335.5 \pm 107.3^{\mathrm{a}}$ \\
\hline Fertilization & $272.5 \pm 77.4^{\mathrm{b}}$ & $382.0 \pm 97.4^{\mathrm{b}}$ & $478.5 \pm 102.4^{\mathrm{b}}$ & $377.7 \pm 122.5^{\mathrm{b}}$ \\
\hline Clipping & $314.1 \pm 76.9^{b c}$ & $406.6 \pm 78.2^{\mathrm{bc}}$ & $507.5 \pm 91.8^{b c}$ & $409.4 \pm 111.9^{\mathrm{bc}}$ \\
\hline Fertilization and clipping & $328.2 \pm 96.9^{\mathrm{c}}$ & $436.2 \pm 89.2^{\mathrm{c}}$ & $599.3 \pm 97.9^{\mathrm{c}}$ & $454.6 \pm 144.9^{\mathrm{c}}$ \\
\hline
\end{tabular}

a, b, c : Within columns, means not sharing a common superscript differ significantly $(\mathrm{p}<0.05)$

Table 3. Crude protein content $(\%)$ for the 2004, 2005 and 2006 seasons at different treatments

\begin{tabular}{|c|c|c|c|c|}
\hline \multirow[b]{2}{*}{ Treatments } & \multicolumn{3}{|c|}{ Year } & \multirow{2}{*}{$\begin{array}{l}\text { Average } \\
2004-2006\end{array}$} \\
\hline & 2004 & 2005 & 2006 & \\
\hline Control & $8.04 \pm 1.22^{\mathrm{a}}$ & $8.32 \pm 1.33^{\mathrm{a}}$ & $8.41 \pm 1.26^{\mathrm{a}}$ & $8.26 \pm 1.19^{a}$ \\
\hline Fertilization & $9.56 \pm 1.15^{\mathrm{b}}$ & $9.11 \pm 1.18^{\mathrm{b}}$ & $8.86 \pm 1.28^{\mathrm{a}}$ & $9.18 \pm 1.15^{b}$ \\
\hline Clipping & $9.36 \pm 0.83^{b}$ & $10.06 \pm 1.27^{\mathrm{b}}$ & $10.33 \pm 1.34^{\mathrm{b}}$ & $9.92 \pm 1.17^{\mathrm{b}}$ \\
\hline Fertilization and clipping & $8.72 \pm 1.56^{b}$ & $9.45 \pm 1.35^{\mathrm{b}}$ & $9.87 \pm 1.68^{b}$ & $9.35 \pm 1.50^{b}$ \\
\hline
\end{tabular}

${ }^{\mathrm{a}, \mathrm{b}}$ : Within columns, means not sharing a common superscript differ significantly $(\mathrm{p}<0.05)$ 
Am. J. Environ. Sci., 4 (6): 551-557, 2008

Table 4: Seasonal rain use efficiency (S-RUE) at different treatments

\begin{tabular}{|c|c|c|c|c|}
\hline \multirow[b]{2}{*}{ Treatments } & \multicolumn{3}{|c|}{ Year } & \multirow[b]{2}{*}{$\begin{array}{l}\text { Average } \\
2004-2006\end{array}$} \\
\hline & 2004 & $\begin{array}{l}2005 \\
\mathrm{DM} \mathrm{ha}^{-1} \mathrm{~mm}^{-}\end{array}$ & 2006 & \\
\hline Control & $1.33 \pm 0.24^{\mathrm{a}}$ & $1.88 \pm 0.26^{\mathrm{a}}$ & $2.15 \pm 0.19^{\mathrm{a}}$ & $1.78 \pm 0.22^{\mathrm{a}}$ \\
\hline Fertilization & $1.42 \pm 0.27^{\mathrm{ab}}$ & $2.05 \pm 0.32^{\mathrm{ab}}$ & $2.38 \pm 0.28^{\mathrm{ab}}$ & $1.95 \pm 0.29^{\mathrm{ab}}$ \\
\hline Clipping & $1.67 \pm 0.31^{\mathrm{ab}}$ & $2.40 \pm 0.38^{\mathrm{ab}}$ & $2.78 \pm 0.36^{\mathrm{ab}}$ & $2.28 \pm 0.35^{\mathrm{ab}}$ \\
\hline Fertilization and clipping & $1.55 \pm 0.22^{\mathrm{b}}$ & $2.42 \pm 0.63^{\mathrm{b}}$ & $3.09 \pm 0.65^{\mathrm{b}}$ & $2.35 \pm 0.50^{\mathrm{b}}$ \\
\hline
\end{tabular}

Averaged of 3 years, the crude protein content in the forage dry matter was $8.26 \%$ in control plots in the present study. All treatments increased $(p<0.05)$ the crude protein content in the forage dry matter but the $\mathrm{CP}$ content from each treatment did not differ between the 3 study years. The application of $\mathrm{N}$ plus $\mathrm{P}$ did not influence the crude protein content significantly ( $>0.05)$ if compared with other treatments. When comparing average crude protein content over the 3 years, the values from the clipping of Phlomis fruticosa application were 6.1 and $8.1 \%$ respectively higher than that from clipping of fertilization and from the clipping combined with fertilization application.

This effect can be explained by the observation that the clipping of Phlomis fruticosa resulted in higher legume proportion than from nitrogen and phosphorus fertilization. In fact, $\mathrm{N}$ application reduces legume proportion $^{[16]}$ while $\mathrm{P}$ fertilizer increases legume proportion in vegetation ${ }^{[10]}$. Also, the reason of higher crude protein content at treatment with clipping of Phlomis fruticosa than the other treatments during years may be the fact that cutting performed in the plots every year increase the legumes proportion in vegetation ${ }^{[15]}$.

As the protein concentration in legume plants is always considerably higher than that in the grass and other species, variations in crude protein content of the treatments were due to relative proportions of legumes, grasses and other families in forage dry matter.

Increases of crude protein content due to fertilizer application have been reported in numerous studies $^{[2,14,1525,29,34]}$.

All treatments did not significantly affect seasonal rain-use efficiency (S-RUE). The S-RUE (expressed in terms of forage production) from clipping combined with fertilization treatment were higher $(\mathrm{p}<0.05)$ than control for all growing seasons (Table 4). The average S-RUE of fertilization, clipping and fertilization combined with clipping treatments was respectively $1.95,2.28$ and $2.35 \mathrm{~kg}$ forage produced.

It is noteworthy that low S-RUE occurred in all fertilization treatments, regardless of very high rainfall during the growing seasons. The main reason for this insufficient rain use may be the poor rangeland conditions. Actually, Le Houerou ${ }^{[19]}$ reviewed rain-use
Efficiency (RUE) in 179 sets of data and also argued that it primarily reflected perennial acrial biomass and ground cover, with RUE being substantially lower in degraded ecosystems or considerably higher in pristine conditions. After the first season S-RUE increased annually in all fertilization treatments. This is largely due to an increase in forage production from the second year.

The seasonal average S-RUE over the experimental period obtained from the control $(1.78 \mathrm{~kg}$ forage $\mathrm{ha}^{-1} \mathrm{~mm}^{-1}$ ) in this study can be compare well with these obtained by Snyman ${ }^{[31,32]}$ in a semi-arid climate of South Africa, which varied between 3.48 and $2.00 \mathrm{~kg}$ $\mathrm{ha}^{-1} \mathrm{~mm}^{-1}$ and the $2.4 \mathrm{~kg} \mathrm{ha}^{-1} \mathrm{~mm}^{-1}$ of Guevara et al. ${ }^{[9]}$ in a temperate-warm climate of Argentina.

In addition to that, the water losses through evaporation, surface runoff and deep drainage were not taken in account, contributing to the underestimation of the rain use efficiency. Turner ${ }^{[37]}$ reported that agronomic practices that reduce water losses and improves crop yield increases RUE. Agronomic procedures such as minimum tillage, appropriate fertilizer use, improved weed/disease/insect control, timely planting and a range of rotation options are example of practices to increase RUE.

The increase in forage production per $\mathrm{kg}$ fertilizer applied with and without clipping of Phlomis fruticosa were 21.1 and $59.5 \mathrm{~kg}$ respectively on average over the 3 years for all fertilizer treatments (Fig. 1). These values are higher than those obtained by ${ }^{[9]}$ for a temperate-warm climate in Argentina and lower than those obtained by Snyman ${ }^{[34]}$ for a semi arid climate of South Africa. According to Rubio et al. ${ }^{[29]}$ and Snyman ${ }^{[34]}$, nutrient use efficiency increases as the growing season rainfall increases. This did not observed to this study maybe because of the high rainfall of all seasons and the poor range conditions.

Stocking rate, in animal unit months, was 321,716 , $8 \%$ below the estimated grazing capacity Fig. 2 . In all improvement treatments, grazing capacity was higher than stocking rate only at the third period. Among the improvement treatments, the grazing capacity was lowest at $\mathrm{N}+\mathrm{P}$ fertilization treatment where forage production was the lowest. On the other hand, the 


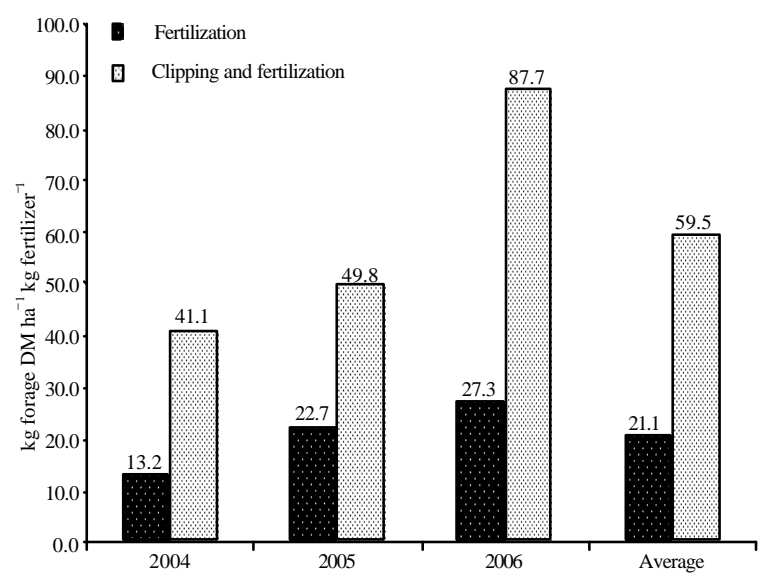

Fig. 1: Nutrient use efficiency on a Thesprotia Prefecture phryganic rangeland at different treatments, 2004-2006

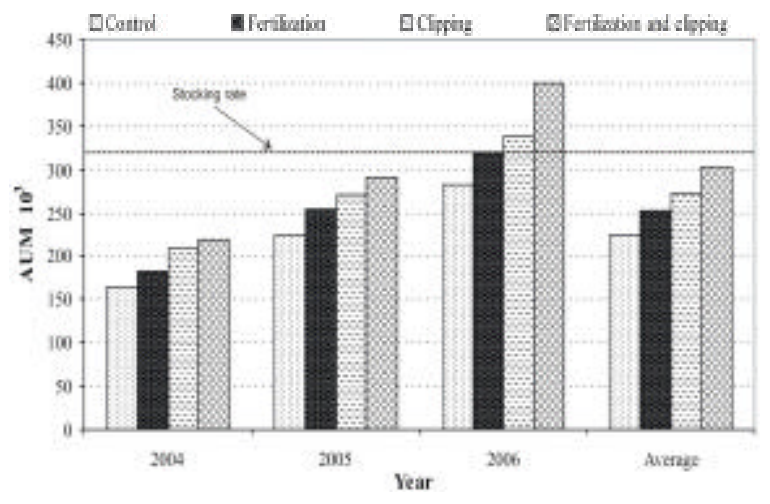

Fig. 2: Grazing capacity of Thesprotias' Prefecture phryganic rangelands during 2004-2006 at different treatments

grazing capacity of treatment that includes clipping of Phlomis fruticosa combined with $\mathrm{N}+\mathrm{P}$ fertilization was higher than the other treatments, with forage production higher than the other treatment plots.

Although, determining grazing capacity is a controversial subject due to an abundance of factors influencing its determination ${ }^{[28,11]}$, the results of the present study leads to a confirmation of the widespread belief that actual stocking rate exceeds the grazing capacity of the plain. Accordingly, the mean grazing capacities of the study districts revealed that more land is required to sustain an Animal Unit without damaging the rangeland ecosystem. The estimation of grazing capacity in this study was undertaken to give an indication of the extent of the problem in the study districts.

\section{CONCLUSION}

The results of present study support conventional wisdom stating that the phryganic rangeland ecosystems of Thesprotia Prefecture are ecological degraded as a result from high stocking rates application. It confirmed that Jerusalem sage (Phlomis fruticosa L.) is a very competitive plant that constitutes the main restrictive factor for the increase of rangeland production and its crude protein content. This does not allow the phryganic rangeland to respond directly to fertilization and clipping, affair that is justified by the low values of S - RUE and NUE.

In order to improve the Thesprotia phryganic rangeland, which is in poor condition under communal type of ownership, combination of clipping of Phlomis fruticosa L. and moderate fertilization for a period of 3 years are required. Furthermore, the poor rangeland condition as documented in the study and the need for improvement of the rangelands require a strong participation of the local pastoralists and local munic ipalities.

Nevertheless, it is necessary to find out the economic benefits that may be derived from clipping of Phlomis fruticosa L. and applying $\mathrm{N}$ and $\mathrm{P}$ to rangeland, the viability and feasibility of such a practice depends on whether or not it induces long-term or even shorter term undesirable impacts in the rangeland ecosystem. Thus, if sustainability of phryganic rangeland ecosystems is to be achieved, a proper management plan with rangeland improvement practices is crucial to be fund for minimize the further degradation of the rangeland ecosystem.

\section{ACKNOWLEDGEMENT}

This study is a by-product of the EPEAEK II project Environment-Archimedes: A support of research in issues of environment and ecology in Technological Education Institutes financed $75 \%$ by EC (European Social Fund) and $25 \%$ by the Greek Government.

\section{REFERENCES}

1. Alifakiotis, T., K. Papanikolaou, A. Karalazos, D. Ntotas, D. Liamadis and G. Gavriilidis. 1989. The Rangelands of Thesprotia Prefecture: Study of existing situation and improvement and management proposals. Igoumenitsa (In Greek).

2. Aydin I. and F. Uzun, 2005. Nitrogen and phosphorous fertilization of rangelands affects yield, forage quality and the botanical composition. Eur. J. Agron., 23: 8-14. 
3. Berg, W.A. and P.L. Sims, 1995. Nitrogen fertilizer use efficiency in steer gain on Old World bluestem. J. Range Manage., 48: 465-469.

4. Booysen, P. de V., 1980. Pasture improvement possibilities in effective animal production systems. South Afr. J. Anim. Sci., 10: 293-298.

5. Cilliers, J.W., P.L. Van Biljon, E. Tolmay and C. Coertze, 1997. Effects of different levels of fertilizer application to veld on growth of steers and chemical composition of the herbage. Grass Forage Sci., 52: 242-248.

6. Debazac, E.P. and G. Mavrommatis. 1969. Note sur les formations forestieres a feuilles persistantes en Grece. Inst. Rech. Forest, Athenes, pp: 23.

7. De Waal, H.O., 1990. Animal production from native pasture (veld) in the Free State Region-a perspective of the grazing ruminant. South African J. Anim. Sci., 20: 1-9.

8. Greuter W., H. Burdet and G. Long, 1986. MedChecklist, Vol. 3, Conservatoire et Jardin Botaniques, Ville de Geneve, 310.

9. Guevara, J.C., C.R. Stasi, O.R. Estevez and H.N. Le Houerou, 2000. N and P fertilization on rangeland production in Midwest Argentina. J. Range Manage., 53: 410-414.

10. Henkin, Z., N.G. Seligman, I. Noy-Meir, U. Kafkafi and M. Gutman, 1998. Rehabilitation of mediterranean dwarf-shrub rangeland with herbicides, fertilizers and fire. J. Range Manage., 51: 193-199.

11. Holechek, J.L. and D. Galt, 2000. Grazing intensity guidelines. Rangelands, 21: 11-14.

12. Kalmbacher, RS. and F.G. Martin, 1988. Effect of defoliation frequency and NP-K fertilization on maidencane. J. Range Manage., 41: 235-238.

13. Kalmbacher, R.S., F.G. Martin and J.E. Rechcigl, 1993. Effect of NP-K fertilization on yield and tiller density of creeping bluestem. J. Range Manage., 46: 452-457.

14. Kandrelis, S.S., 1990. Effects of clipping, burning and fertilization on Phlomis fruticosa L. and improvement of forage production in phryganic rangelands. M.Sc. Thesis, M.A.I.Ch. Chania, Greece.

15. Kandrelis, S.S., 1995. Effect of clipping and burning on Phlomis fruticosa L. reproduction and their implications on the productivity of phlometum ecosystem. Ph.D. Thesis. Thessaloniki, Greece (In Greek).

16. Kim, M.C., H.N. Hyun and S.C. Lee, 2000. Botanical composition, herbage production and plant mineral contents as affected by application of chemical fertilizer and fermented sawdust pig manure on Cheju brown volcanic ash pasture soil. J. Korean Soc. Grassland Sci. 20, 131-138.
17. Kypasissis, A. and Y. Manetas, 1993. Seasonal leaf dimorphism in a semi-deciduous Mediterranean shrub: Ecophysiological comparisons between winter and summer leaves. Anta Ecol., 14: 23-32.

18. Kyparissis A., G. Grammatikopoulos and Y. Manetas, 1997. Leaf demography and photosynthesis as affected by the environment in the drought semi-deciduous Mediterranean shrub Phlomis fruticosa L. Acta Oecol., 18: 543-555.

19. Le Houerou, H.N., 1984. Rain use efficiency: A unifying concept in arid-land ecology. J. Arid Environ., 7: 213-247.

20. Nielsen, E.T. and W.H. Muller, 1981. Phenology of drought deciduous shrub Lotus scoparius: Climatic controls and adaptive significance. Ecol. Monographs, 51: 323-341.

21. Minson, D.J. and C.K. McDonald, 1987. Estimating forage intake from the growth of beef cattle. Trop. Grasslands, 21: 116-122.

22. Orshan, G., 1963. Seasonal Dimorphism of Desert and Mediterranean Chamaephytes and its Significance as a Factor in their Water Economy. ln: The Water Relations of Plants, Rutter, A.J. and E.H. Whitehead, (Eds.). Blackwell, Oxford, pp: 206-222.

23. Papanastasis, V.P., 1977. Fire ecology and management of phrygana communities in greece. In: Proceeding Symposium of Environmental Consequences of Fire and Fuel Management in the Mediterranean Ecosystems. Mooney, H.A. and C.E. Conrad (Tech. Coords). US. Dep. Agr., Forest Serv., General Tech. Rep. WO-3, pp: 476-482.

24. Papanastasis, V.P., 1980. Effects of season and frequency of burning on a phryganic rangeland in Greece. J. Range Manage., 33: 251-255.

25. Papanastasis, V.P. and P.H. Koukoulakis, 1988. Effects of fertilizer application to grasslands in Greece. Grass Forage Sci., 43: 151-158.

26. Papanastasis, VP. and V.I. Noitsakis, 1992. Rangeland ecology. Giaxoudi Press, Thessaloniki.

27. PRISMA, Ltd. 2000. Land-planning study of Thesprotia Prefecture (In Greek). Athens.

28. Roe, E.M., 1997. Viewpoint: On rangeland carrying capacity. J. Range Manage., 50: 467-472.

29. Rubio, H.O., M.K. Wood, A. Gormez and G. Reyes, 1996. Native forage quality, quantity and profitability as affected by fertilization in northern Mexico. J. Range Manage., 49: 315-319.

30. SPSS, Inc., 2003. SPSS for Windows. SPSS Inc.

31. Snyman, H.A., 1998. Dynamics and sustainable utilisation of rangeland ecosystems in arid and semi-arid climates of southern Africa. J. Arid Environ., 39: 645-666. 
32. Snyman, H.A., 1999. Short-term effect of soilwater, defoliation and rangeland condition on productivity of a semi-arid rangeland in South Africa. J. Arid Environ., 43: 47-62.

33. Snyman, H.A., 2000. Soil-water utilisation and sustainability in semi -arid grassland. Water South Africa, 26: 331-341.

34. Snyman, H.A., 2002. Short-term response of rangeland botanical composition and productivity to fertilization ( $\mathrm{N}$ and $\mathrm{P}$ ) in a semi-arid climate of South Africa. J. Arid Environ., 50: 167-183.

35. Steel, R.G. and J.H. Torrie, 1980. Principles and procedures of statistics. McGraw-Hill Book Co., New York.
36. Soulis, N.V., 1994. The climate of Epirus. Ioannina (In Greek).

37. Turner, N.C., 2004. Agronomic options for improving rainfall-use efficiency of crops in dryland farming systems. J. Exp. Bot., 55: 2413-2425.

38. Westman, W.E., 1981. Seasonal dimorphism of foliage in Californian coastal sage shrub. Ecologia, 51: 385-388.

39. Zervas, G., P. Kalaisakis and K. Feggeros, 2004. Farm Animals Nutrition. 2nd Edn. Stamoulis Editions, Athens (In Greek). 